\title{
Intrinsic Vulnerability Assessment of a Confined Carbonatic Aquifer: the Brindisi Plain Case (Southern Italy)
}

\author{
N. Lopez, D. Sciannamblo, M. Spizzico*, V. Spizzico and R. Tinelli \\ Department of Civil and Environmental Engineering - Polytechnic of Bari, Bari, Italy
}

\begin{abstract}
Apulia, in the absence of surface water, is one of the Italian regions which satisfy their water requirements by drawing large quantities (over 40\%) of its water from underground resources. The large amounts drawn from these resources in the last few years due to increasing human activity on the territory has determined a general and inevitable reduction of the quality of the underground water resources although they circulate in hydrogeological and geostructural environments characterised by a low intrinsic vulnerability. This is particularly true in the Brindisi Plain: a large portion of territory between the Serre Salentine and the Adriatic Sea. The area examined is characterised by the existence of two distinct hydrogeological environments one overlying the other; in the underlying one, made up of Mesozoic carbonate deposits, there is a groundwater body of significant size which satisfies about $30 \%$ of the requirements; in the one overlying this, made up of Quaternary calcarenite-sandy deposits, there is a groundwater body of reasonable local importance. For each aquifer, the study evaluated the intrinsic vulnerability using a parametric model, SINTACS, standardised for Italy and modified by the authors in order to adapt it to the particular characteristics of the examined zone. The information obtained in this way was then compared with the quality of the waters circulating in these aquifers. The investigations showed the generally good quality of the waters circulating in the carbonate aquifer and the presence of pollution by nitrates in the vicinity of some wells. By analysing the maps drawn up and from the information collected in situ, it was possible to ascertain that widespread forms of underground water pollution can be blamed on the poor execution of drilled wells and on the lack of suitable management criteria of the groundwater bodies.
\end{abstract}

\section{INTRODUCTION}

In Southern Italy the increase of craft and industrial estates as well as farming land and the expansion of urban settlements have led to an increase of the exploitation of the territory and its resources. In particular, the increasing need for water is satisfied by extending the already widespread phenomenon of groundwater catchment, which has consequentially determined a reduction of the underground water resource quality in Apulia, a problem of significant importance for a region with a historical absence of surface water resources.

The area being studied comes completely within the Brindisi Plain (Apulia, Italy), covers about $550 \mathrm{Km}^{2}$ and is mainly flat or sublevel with hight differences ranging from sea level to the 166 metres of Oria. The drainage network is undeveloped and the main rivers (around $30 \mathrm{~km}$ long) are located around the city of Brindisi. In the area there is intense agricultural and farming activity and a significant number of wells have been created in the shallow groundwater ("dug" wells) as well as in the deep groundwater ("drilled" wells).

The territory is characterised by the presence of two distinct overlying hydrogeological environments extending almost its whole length. The first environment consists of Mesozoic carbonate deposits and is where the main regional aquifer is located, the other one overlying this is represented

*Address correspondence to this author at the Department of Civil and Environmental Engineering - Polytechnic of Bari, Bari, Italy; Tel: +39 0805963676; Fax: +39 0805963675; E-mail: m.spizzico@poliba.it by the Quaternary calcarenite-sandy deposits where a locally important aquifer is located.

Therefore, considering the articulated hydrogeological characteristics of the territory being examined, partially already described in literature [1-4], this study was performed to check whether the intrinsic vulnerability of both the aquifers obtained, could be confirmed by the chemical-physical characteristics of both groundwater: the "deep" one and the "shallow" one.

For vulnerability assessment the SINTACS parametric method has been adopted. The SINTACS was created and developed by Civita [5-6] for fitting the DRASTIC model [7] to two main conditions: 1) the hydrogeologic, climatic and impact settings that are typical of the Italian territory and of the Mediterranean basin; 2) the basic data really available in a country where no Agency exists for the collection and publication of hydrogeologic, pedological, hydrologic informations etc. as is normal in the USA and in some other European countries.

The SINTACS, originally shaped in a similar way to DRASTIC, has become different, since 1990, together with the research advancement and a great number of tests; nowadays, it represents a tool with a remarkable degree of flexibility and optimization of data management and analysis, also by virtue of its implementation in GIS environment, to the vulnerability studies of different aquifers founded in Mediterranean basin [8-11].

For determining and controlling the parameters used in the method of evaluating the vulnerability, we were able to survey over 150 "dug" and "drilled" wells belonging to Public Authorities and Private individuals. 
For the necessary investigations on the chemical-physical characteristics of the water bodies, with the previously mentioned "water points" two networks were defined: the first, articulated by about a hundred "dug" wells was used to analyze the waters of the shallow aquifer; the second, made up of 50 "drilled" wells, was used to study the waters of the deep aquifer

\section{GEOLOGIC AND HYDROGEOLOGIC FEATURES OF THE STUDY AREA}

The geology of the territory studied generally reflects the particular geotectonic aspects of the region [12]. The oldest present geological formation (Figs. 1, 2) is the limestone and dolomitic limestone dating back to the Upper Cretaceous, which is the "regional bedrock" where there is the most important groundwater resource in Apulia: the "deep groundwater".

The carbonate bedrock, which outcrops in isolated areas to the north of Mesagne in the study area (Fig. 1), is affected by a double system of faults, mainly oriented in a NW-SE and $\mathrm{E}-\mathrm{W}$ direction and secondarily directed NE-SW, giving them a step-like structure dipping NE towards the Adriatic Sea, where it reaches a depth of -40 metres below average sea level.

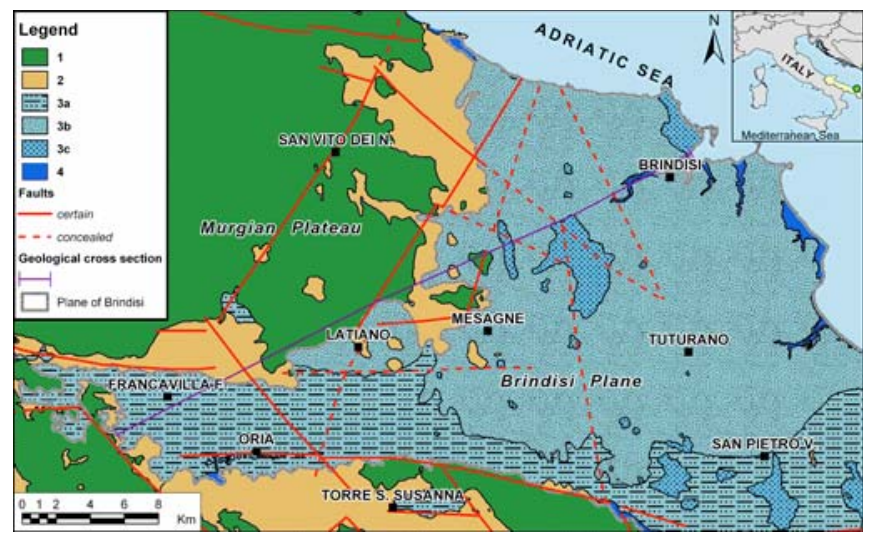

Fig. (1). Geological map of Brindisi Plane. Legend: 1) Dolomitic limestones and limestones (Cretaceous); 2) Calcarenites (Lower Pleistocene); 3) Terraced marine deposits (Middle-Upper Pleistocene): a) sandy-clay facies; b) sandy facies; c) calcarenitic facies; 4) Recent deposits (Holocene).

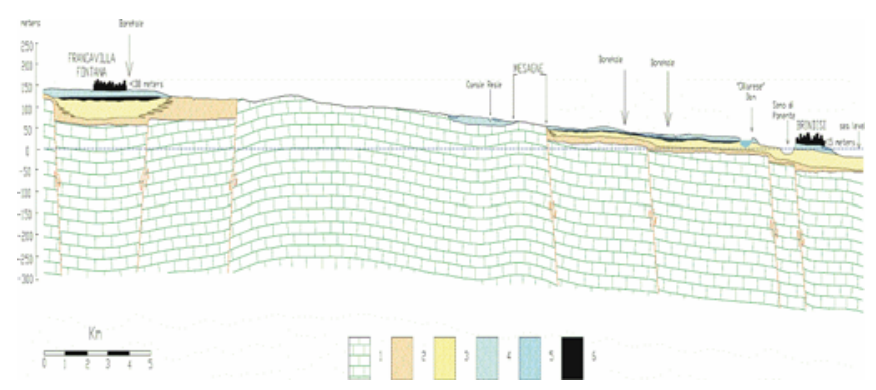

Fig. (2). Geological cross-section along direction Francavilla F. Brindisi (vertical scale is exaggerated). Legend: 1) dolomitic limestones and limestones (Cretaceous); 2) calcareous sandstones (Lower Pleistocene); 3) grey-cyan clays (Lower Pleistocene); 4) terraced marine deposits (Middle-Upper Pleistocene); 5) calcarenitic facies of terraced sea deposits (Middle-Upper Pleistocene); 6) shallow groundwater.
This vast tectonic depression is covered by calcarenite deposits dating back to the Lower Pleistocene, characterised by variable grain size and cementation and by thicknesses not exceeding 30 metres; in the study area these deposits, found in small isolated outcrops, can be considered an upward extension of the cretaceous carbonate aquifer.

The two permeable formations, one because of fissures and karst phenomena and the other because of porosity and fissures have an extremely variable degree of hydraulic conductivity even in small spaces as it has been possible to deduct from the results of the pumping tests carried out on around twenty wells spread out over the territory. The waters circulating in the carbonate aquifer are supplied by the infiltration of rainwater directly through tectonic fractures, karst dolines and sinkholes many of which develop in the outcropping areas of the "calcareous bedrock" [13].

At the top of and in conformity with the calcarenite formation there are the grey-blue marly clays of the Calabrian period, which do not outcrop in the study area and were only found at a depth, from boreholes, where they reach thicknesses of over 50 metres (south-eastern sector); this clayey level creates a barrier preventing the waters of the carbonate groundwater from freely running-off towards the sea and then forces them to circulate under pressure.

In stratigraphic concordance, on the clayey level there are the formations from the Middle-Upper Pleistocene period, which, under the collective name of "terraced marine deposits", include both poorly cemented calcarenites and fine calcareous sands. These deposits of a limited thickness, 20-25 metres at the most, have sub-horizontal bedding and are transgressive on distinct abrasion surfaces, located at different heights (terraces).

In the area the terraced deposits are of two main facies: the first, outcropping between Francavilla Fontana and Mesagne and to the south of Brindisi, consists of poorly cemented calcareous sands, with limestone interbedding; the second facies, outcropping around the city of Brindisi, consists of clayey sands and grey-bluish clays with bioclastic arenaceous and calcarenitic interbedding (Fig. 1).

The "shallow groundwater" circulates in these terraced deposits and, supported at the base by the almost impermeable clayey level, extends without continuity and with loads dictated by the morphology of the soil from the most inland parts of the area to the coast. The groundwater does not suffer the effects of marine intrusion and is supplied exclusively and directly by rainwater. Recent studies have shown an effective infiltration of approximately $40 \%$ of the annual precipitation corresponding to a mean rate of approximately 7 $1 / \mathrm{s} \mathrm{km}^{2}$.

It was also found that the dynamic porosity of the shallow aquifer varies between $18 \%$ and $30 \%$ and that during intense periods of rain, large areas of the territory, more depressed and charaterised by soils with a high percentage of clay, get flooded [14].

\section{THE PARAMETRIC MODEL FOR ASSESSMENT OF GROUNDWATER VULNERABILITY}

Aware of the fact that the vulnerability of the aquifers to pollution depends on different parameters and considering 
Table 1. SINTACS Ratings for Shallow Aquifer

\begin{tabular}{|c|c|c|c|}
\hline $\begin{array}{l}\text { Depth to Ground- } \\
\text { water }(\mathbf{m})-(\mathbf{S})\end{array}$ & Rating & $\begin{array}{c}\text { Unsatured Zone Attenuation } \\
\text { Capacity - (N) }\end{array}$ & Rating \\
\hline $0-1$ & 10 & Sandy Facies & 8 \\
\hline $1.1-2$ & 9 & Sandy-silty Facies & 7 \\
\hline 2.1-4 & 8 & Silty Facies & 6 \\
\hline $4.1-6$ & 7 & Silty-sandy-clayey Facies & 5 \\
\hline $6.1-10$ & 6 & Clayey Facies & 2 \\
\hline 15.1-18 & 4 & $\begin{array}{c}\text { Soil/overburden attenuation } \\
\text { capacity - }(\mathbf{T})\end{array}$ & Rating \\
\hline \multirow[t]{2}{*}{$\begin{array}{l}\text { Effective Infiltra- } \\
\text { tion action - (I) }\end{array}$} & & Scarce soil cover & 10 \\
\hline & & Sandy Soil & 8 \\
\hline Soil texture & $\chi$ & Loamy-sandy Soil & 6 \\
\hline Sandy & 0,5 & Loamy Soil & $4-5$ \\
\hline Silty-sandy & 0,4 & Loamy-clayey Soil & 3 \\
\hline Silty & $0,1-0,2$ & Clayey Soil and terra rossa & 2 \\
\hline Clayey-silty & 0,05 & $\begin{array}{l}\text { Hydrogeologic characteris- } \\
\text { tics of the aquifer - (A) }\end{array}$ & Rating \\
\hline \multirow[t]{2}{*}{ Clayey } & $\begin{array}{l}0,01- \\
0,02\end{array}$ & Sandy Facies & 9 \\
\hline & & Sandy-silty Facies & 8 \\
\hline $\begin{array}{l}\text { Active recharge } \\
(\mathrm{mm} / \mathrm{a})\end{array}$ & Rating & Silty Facies & 7 \\
\hline $251-300$ & 10 & Silty-sandy-clayey Facies & 6 \\
\hline $\begin{array}{l}\text { 201-250 and } 301- \\
325\end{array}$ & 9 & Clayey Facies & 4 \\
\hline $\begin{array}{l}176-200 \text { and } 326- \\
350\end{array}$ & 8 & $\begin{array}{l}\text { Hydraulic conductivity } \\
\text { range of the aquifer }(\mathrm{m} / \mathrm{s})- \\
\text { (C) }\end{array}$ & Rating \\
\hline $126-150$ & 6 & $\geq 1 \times 10^{-4}$ & 8 \\
\hline $101-125$ & 5 & $5 \times 10^{-5}-1 \times 10^{-4}$ & 7 \\
\hline \multirow[t]{7}{*}{$81-100$} & 4 & $1 \times 10^{-5}-5 \times 10^{-5}$ & 6 \\
\hline & & $5 \times 10^{-6}-1 \times 10^{-5}$ & 5 \\
\hline & & $1 \times 10^{-6-} 5 \times 10^{-6}$ & 4 \\
\hline & & $5 \times 10^{-7}-1 \times 10^{-6}$ & 3 \\
\hline & & $\begin{array}{l}\text { Hydrologic role of the topog- } \\
\text { raphic slope }(\%)-(S)\end{array}$ & Rating \\
\hline & & $0-2$ & 10 \\
\hline & & $2-4$ & 9 \\
\hline
\end{tabular}

the entity, the quality and the distribution of the environmental and territorial data available, we took the decision to evaluate the intrinsic vulnerability of the two aquifers by adopting a Point Count System Model (PCSM).
We considered that the (PCSM) S.I.N.T.A.C.S. Release 5 [15] method was particularly suited to the type of area to be studied as it has been approved for application to any part of the Italian territory and is suitable for producing mediumlow scale denominator cartography. Moreover, the method is characterised by a modular structure which allows various lines of multiplier weights to be used alternately and in parallel.

The method assumes some intrinsic characteristics of the territorial environment as "vocational indicators": Depth to groundwater (S), Effective infiltration action (I), Unsaturated zone attenuation capacity $(\mathrm{N})$, Soil/overburden attenuation capacity (T), Hydrogeologic characteristics of the aquifer (A), Hydraulic conductivity (C), Topographic slope (S).

The method foresees the division of the examined territory into Square Finite Elements (SFE); each mesh is then characterised by attributing a rating $(\mathrm{P})$, between 1 and 10 according to its importance in defining vulnerability, and a weight (W), from 1 to 5 , to each of the basic vocational parameters. The weights are related to environmental and anthropogenic local conditions. The vulnerability index is calculated for each cell with the following formula:

$$
I_{\text {SINTACS }}=\sum_{i=1}^{7} P_{i} \times W_{i}
$$

The index ranges from 26 to 260 and is divided into six intervals corresponding to the different vulnerability classes defined by the SINTACS model.

For the area examined an SFE grid with 500 metre side was assumed and each of the seven basic parameters of the method was discriminated as reported in Tables $\mathbf{1 , 2}$.

The basic information has been determined by mapping, bibliography and field surveys; successively, spatial and alphanumeric data have georeferenced and collected using ArcGIS Desktop 9.0 software; finally processing and analysis of parametric and vulnerability maps has been effected by SINTACS R5 Excel plug-in and GIS.

It should be pointed out that the infiltration parameter is calculated by considering the effective rainfall and the surface hydrogeological conditions gathered in the infiltration index $\chi$. This index is determined on the basis of the surface lithology (outcropping or under scarce soil cover) or of the hydraulic features of the soil and of a series of further corrective factors (fractures, karst features, etc.). In the examined area, the evaluation of the infiltration was performed on the basis of monthly rainfall and temperatures of the last six years recorded in the towns of: Francavilla F., Mesagne, San Vito dei Normanni, Tuturano and Brindisi.

As regards the attribution of the values to the parameter aquifer, the hydrogeological features of the saturated zones of the two environments were taken into consideration. Discernment for the "deep" aquifer was performed by defining the degree of faulting and karstification by the effects produced on the water sheet by the continental intrusion sea waters $[13,16]$. For the "shallow" aquifer the discrimination was made on the basis of the lithological features of the different "facies" recognised in the terraced marine deposits. 
Table 2. SINTACS Ratings for Deep Aquifer

\begin{tabular}{|c|c|c|c|}
\hline $\begin{array}{l}\text { Depth to Ground- } \\
\text { water }(\mathbf{m}) \text { - }(\mathbf{S})\end{array}$ & Rating & $\begin{array}{l}\text { Unsatured Zone Attenuation } \\
\text { Capacity - (N) }\end{array}$ & Rating \\
\hline $0-1$ & 10 & $\begin{array}{l}\text { Limestones from little to very } \\
\text { fissured }\end{array}$ & $6-8$ \\
\hline $10-20$ & 5 & Calcarenites & $5-6$ \\
\hline$>20$ & 4 & Sandy clay & $3-4$ \\
\hline \multirow{2}{*}{$\begin{array}{l}\text { Effective Infiltra- } \\
\text { tion action - (I) }\end{array}$} & & Clay & 2 \\
\hline & & $\begin{array}{c}\text { Soil/overburden attenation } \\
\text { capacity - (T) }\end{array}$ & Rating \\
\hline Lithology & $\chi$ & $\begin{array}{l}\text { Surface lithology outcropping } \\
\text { or under scarce soil cover }\end{array}$ & 10 \\
\hline $\begin{array}{l}\text { Karstified lime } \\
\text { stones }\end{array}$ & 0,9 & Sandy soil & 8 \\
\hline Sands & 0,8 & Loamy-sandy Soil & 6 \\
\hline $\begin{array}{l}\text { Fissured lime } \\
\text { stones }\end{array}$ & 0,7 & Loamy Soil & 5 \\
\hline Calcarenites & 0,5 & Loamy-clayey Soil & 3 \\
\hline \multirow[t]{2}{*}{ Clayeys and Silts } & 0,2 & Clayey soil and terra rossa & 2 \\
\hline & & $\begin{array}{c}\text { Hydrogeologic characteristics } \\
\text { of the aquifer - (A) }\end{array}$ & Rating \\
\hline Soil texture & $\chi$ & Karstified limestones & 9 \\
\hline Sandy & 0,5 & $\begin{array}{l}\text { Limestones fissured and little } \\
\text { karstified }\end{array}$ & 8 \\
\hline Silty -Sandy & 0,4 & Limestones little fissured & 7 \\
\hline Silty & $0,1-0,2$ & $\begin{array}{l}\text { Hydraulic conductivity range } \\
\text { of the aquifer }(\mathbf{m} / \mathbf{s})-(\mathbf{C})\end{array}$ & Rating \\
\hline Clayey-silty & 0,05 & $5 \times 10^{-3}-1 \times 10^{-2}$ & 10 \\
\hline \multirow[t]{2}{*}{ Clayey } & $\begin{array}{l}0,01- \\
0,02\end{array}$ & $1 \times 10^{-3}-5 \times 10^{-3}$ & 9 \\
\hline & & $5 \times 10^{-4}-1 \times 10^{-3}$ & 8 \\
\hline $\begin{array}{l}\text { Active recharge } \\
\qquad(\mathrm{mm} / \mathrm{a})\end{array}$ & Rating & $1 \times 10^{-4}-5 \times 10^{-4}$ & 7 \\
\hline $\begin{array}{l}151-175 \text { and } 351- \\
375\end{array}$ & 7 & $5 \times 10^{-5}-1 \times 10^{-4}$ & 6 \\
\hline $\begin{array}{l}126-150 \text { and } 376- \\
400\end{array}$ & 6 & $1 \times 10^{-5}-5 \times 10^{-5}$ & 5 \\
\hline $\begin{array}{c}101-125 \text { and } 401- \\
450\end{array}$ & 5 & $5 \times 10^{-6}-1 \times 10^{-5}$ & 4 \\
\hline $81-100$ and $>451$ & 4 & $\begin{array}{l}\text { Hydrologic role of the topog- } \\
\text { raphic slope }(\%)(S)\end{array}$ & Rating \\
\hline $41-60$ & 2 & $0-2$ & 10 \\
\hline$<40$ & 1 & $2-4$ & 9 \\
\hline
\end{tabular}

For both aquifers the hydraulic conductivity was quite variable with the depths and from zone to zone.

Absorption and pumping tests indicate that in the "shallow" aquifer the permeability coefficient varies from $5 \times 10^{-8}$ $\mathrm{m} / \mathrm{s}$ to $1 \times 10^{-6} \mathrm{~m} / \mathrm{s}$. In the SFE without "water points", the rating was attributed by assuming the pedological map of Apulia as a reference [17] and considering the existing relations between texture, structure and hydraulic conductivity in saturated soils defined by Dent and Young [18] and by Landon [19].

The hydraulic conductivity in the base dolomitic limestone formation was found to vary in the same way with values between $1 \times 10^{-6} \mathrm{~m} / \mathrm{s}$ and $5 \times 10^{-2} \mathrm{~m} / \mathrm{s}$ [13].

As regards the parameter regarding the topographic slope, 2 classes of slope were determined coming from a DEM (Digital Elevation Model) with resolution of $100 \mathrm{~m}$.

After attributing ratings to each of the seven parameters for each individual SFE, we characterized the hydrogeological situation and the impact of the site with an appropriate "weight string".

\section{ASSESSMENT OF INTRINSIC VULNERABILITY FOR SURFACE AND DEEP AQUIFER}

The method foresees that the "weight strings" can be the same number as the possible combinations whose sum of the weights of each string is 26 . Indeed, each weight string is made up of 7 figures; each figure is a multiplier which can vary between 1 and 5 and is used to make one or another of the basic parameters of the method stand out.

In the areas examined, there are mainly built up areas and small pieces of land used for growing various crops; from previous analyses [13] the following division of the land has been calculated: urban, industrial and tourist areas $35 \%$ and the remaining $65 \%$ agricultural land, mainly used for intensive farming and tree cultivation.

The "weight strings" processed for characterizing the territory examined are reported in Table $\mathbf{3}$.

Table 3. Weight Strings Adopted for the Application of the SINTACS

\begin{tabular}{|c|c|c|c|c|c|c|c|}
\hline WEIGHT STRING & S & I & N & T & A & C & S \\
\hline \hline Normal Impact & 5 & 4 & 5 & 3 & 3 & 3 & 3 \\
\hline Significant Impact & 5 & 5 & 4 & 4 & 3 & 3 & 2 \\
\hline Relevant Impact & 5 & 5 & 4 & 5 & 3 & 2 & 2 \\
\hline Deep karstified terrain & 2 & 5 & 1 & 3 & 5 & 5 & 5 \\
\hline Fissured terrain & 3 & 3 & 3 & 4 & 4 & 5 & 4 \\
\hline Coastal Impact & 1 & 5 & 2 & 5 & 5 & 5 & 3 \\
\hline
\end{tabular}

As already mentioned, for the field observations we used: 1) a network of approximately 100 "dug" wells, all located in the "shallow" aquifer at a variable depth of between 3 and 20 metres; 2) an articulated network of approximately 50 "drilled wells", with $\varnothing=300 \mathrm{~mm}$ and variable depth from 30 to $150 \mathrm{~m}$, designed to draw the water from the "deep" aquifer.

Four on-site measurement cycles for ascertaining chemical-physical parameters of the waters of the two aquifers were performed on these wells (water levels and multiparametric logs) along with the same number of samples for their chemical and qualitative characterisation (main con- 
stituents, groups of nitrogen, etc). The cycles represents four specific conditions occurring in aquifer during the hydrological year:

- June: regular rate of water withdrawals and reduced supply from upstream;

- July: peak ground water withdrawals (phase of almost complete depletion);

- October: roughly end of withdrawals and of the water depletion phase;

- March: no water withdrawals; groundwater recharge phase.

On the basis of the operations performed on the site, for the "shallow groundwater" we found: the seasonal cycle of the water resource; the strict dependence on rainfall; modest flows; variability of the water thicknesses; the defined preferential flow off directions which emerge clearly from the morphology of the water-table (Fig. 3).

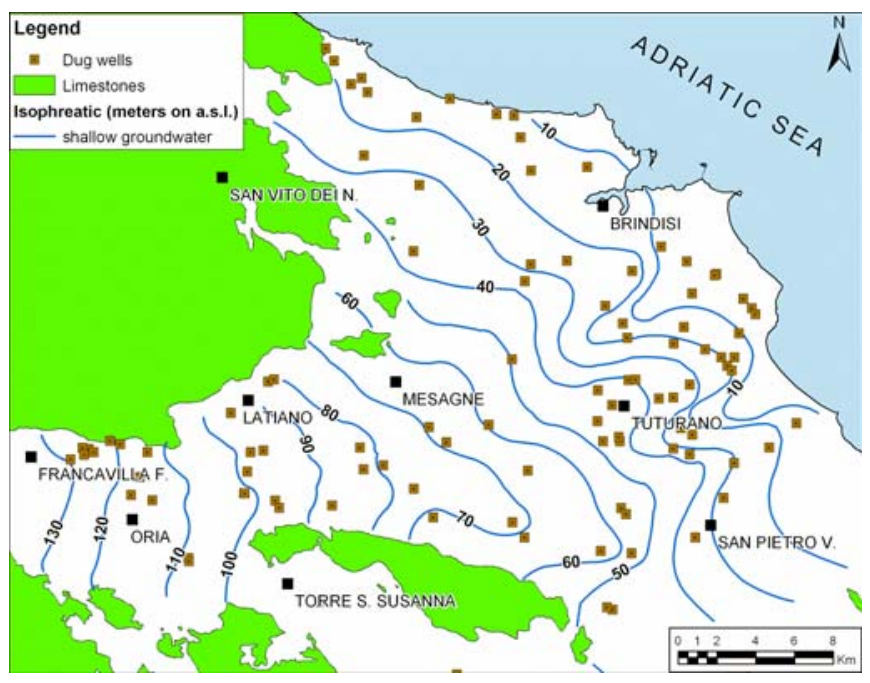

Fig. (3). Isophreatic of shallow groundwater.

For the same groundwater, determination of the concentrations of the main chemical constituents made it possible to classify the waters as bicarbonate-calcium with a chlorinesodium influence (Fig. 4); the chlorine-sodium aspect confirms the evolution of the calcarenite-sandy deposits occurring in a marine environment. The salt concentration of the waters ranges in places between 0.5-1.2 g/l (Fig. 5) and the

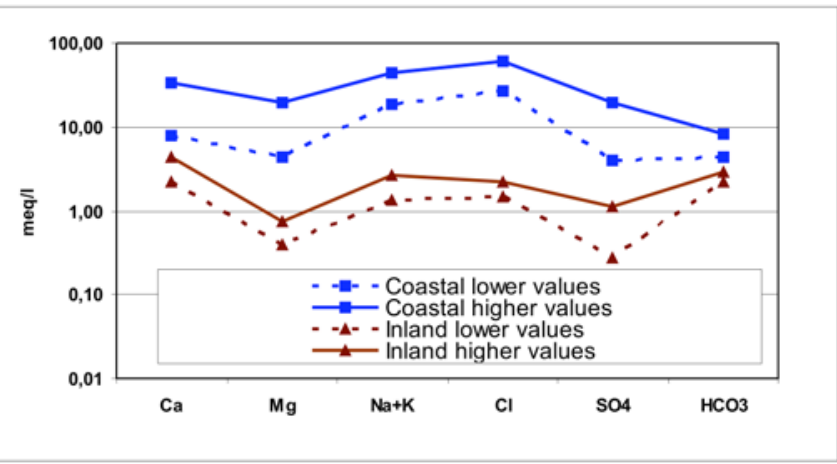

Fig. (4). Chemical characterization of shallow groundwater on the coast near Brindisi (blue color) and in inland areas (brown color). tests showed that the saline content of the waters generally tends to increase with depth. In the coastal area, the salinity remains mainly connected to particular lithological and structural situations and to the phenomenon of seawater intrusion; this implies that at short distances and from zone to zone, the water sheet waters may show a variability of salt of up to $2 \mathrm{~g} / \mathrm{l}$.

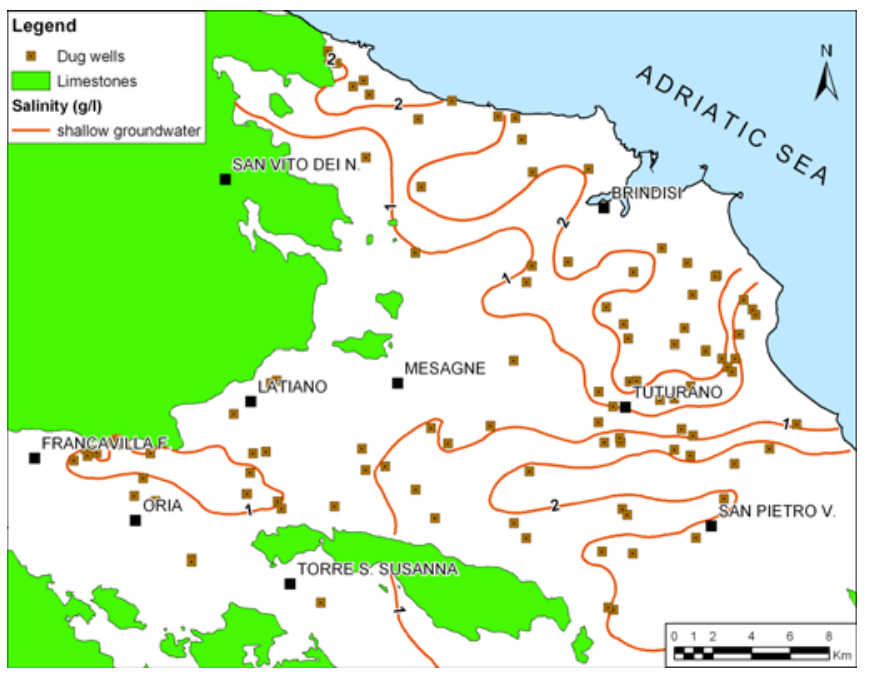

Fig. (5). Salinity map of shallow groundwater.

For the "deep groundwater", the morphology of the piezometric surface (Fig. 6) shows that the groundwater flows off towards the sea is significantly dependant on the rock fissure features. This different degree of permeability is indicated by the variability of the distances between the isopiezometric lines that, in the area studied, range from $0.05 \%$ and $0.5 \%$. It has also been ascertained that the waters mainly have a salinity of $0.30 \mathrm{~g} / \mathrm{l}$ and that in proximity of the coast, they change their connotation from bicarbonate-calcium to chloride-sodium (Fig. 7), in spite of the saline concentration remaining low, between just 1.60 and $1.80 \mathrm{~g} / \mathrm{l}$ (Fig. 8).

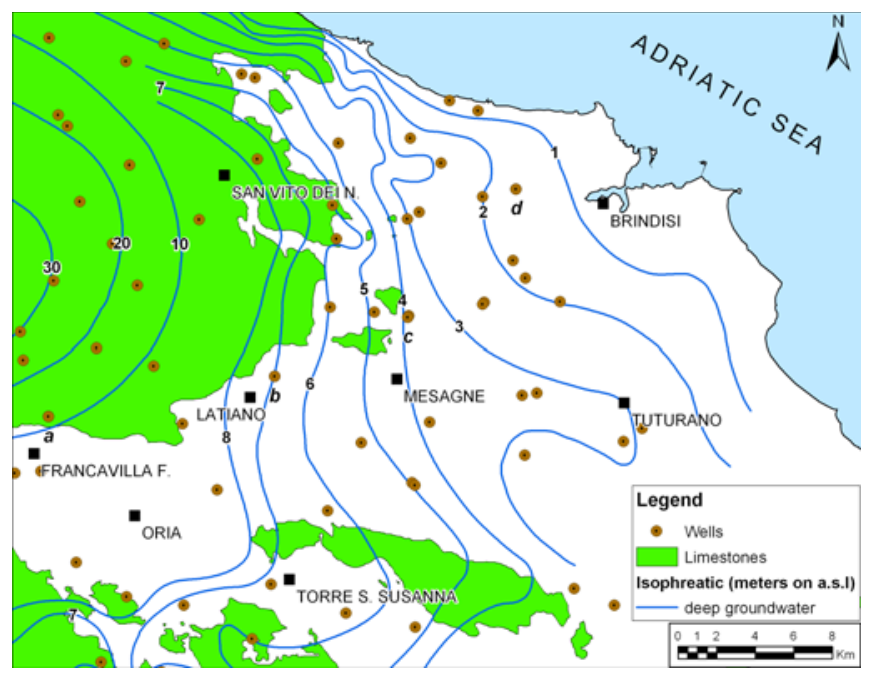

Fig. (6). Piezometric surface of deep groundwater; letters mark the wells used for chemical characterization of deep groundwater (see figure 7). 
As regards the quality of the waters from the two aquifers, the analyses have shown that the "shallow groundwater" is affected by two types of pollution: saltwater pollution, which has been mentioned before, and anthropogenic pollution from the settlements and the agricultural activity. In the area, irrigation starts around the middle of May and at the end of June over $70 \%$ of the "water points" sampled already have concentrations of ammonia nitrogen, nitrites, nitrates and phosphates exceeding the M.A.C. (Maximum Admitted Concentrations) foreseen by the laws in force [20].

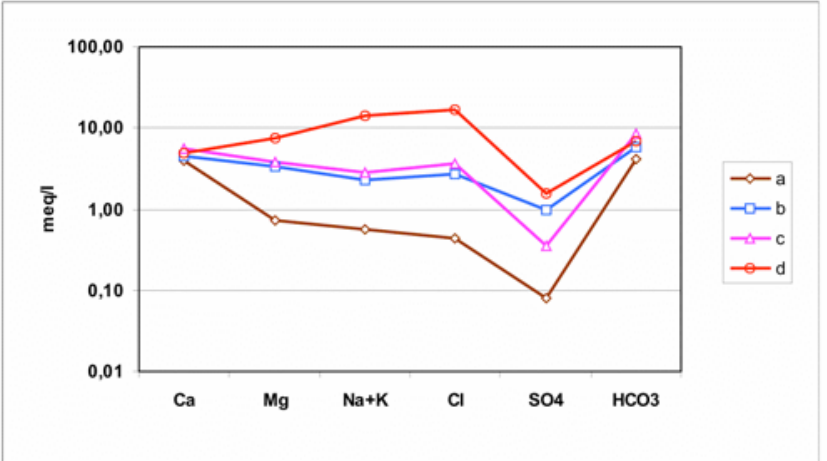

Fig. (7). Chemical characterization of deep groundwater from inland areas (a) to coastal belt (d).

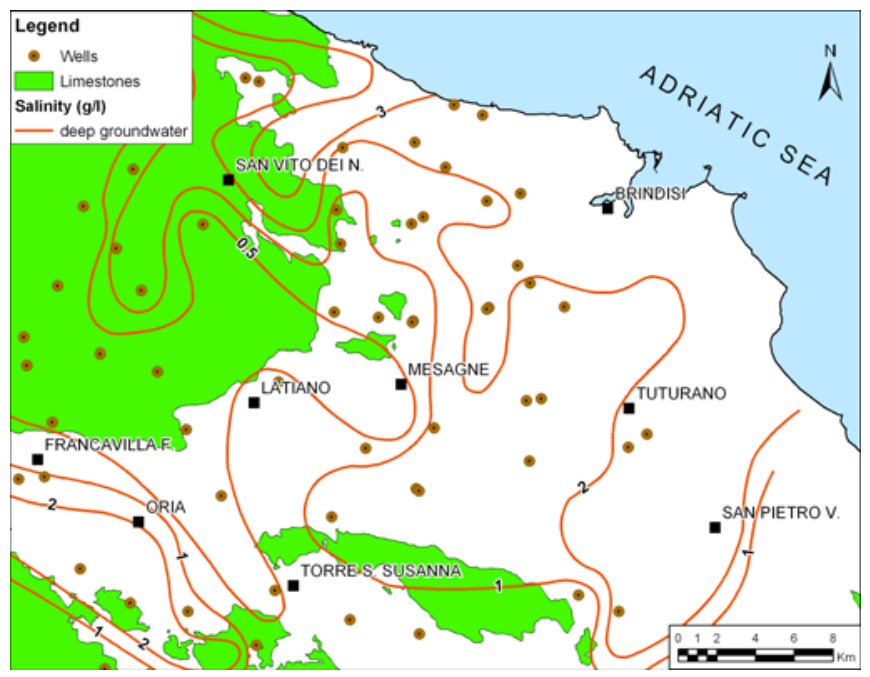

Fig. (8). Salinity map of deep groundwater.

The experimental data were used to produce a map of the spatial distribution of the nitrates [21], whose estimate was obtained by means of geostatic techniques [22]. This evaluation was obtained by using ordinary kriging [22-23], by adapting an isotropic model with double spherical structure (Range $1=2000 \mathrm{~m}$ and Range $2=7600 \mathrm{~m}$ ), plus a nugget effect and by interpolating the variable to the nodes of a grid with a square cell with a 100 metres side, superimposed over the study area.

The map of nitrate concentrations, reported in Fig. (9), shows a classification scheme based on three "classes" of "anthropogenic impact" proposed by the Italian laws in force (Decree Law 152/06): 1) reduced anthropogenic impact $\mathrm{NO}^{3-}$ $\leq 25 \mathrm{mg} / \mathrm{l} ; 2$ ) significant anthropogenic impact $25<\mathrm{NO}^{3-}<$ $50 \mathrm{mg} / \mathrm{l} ; 3$ ) important anthropogenic impact $\mathrm{NO}^{3-}>50 \mathrm{mg} / \mathrm{l}$.

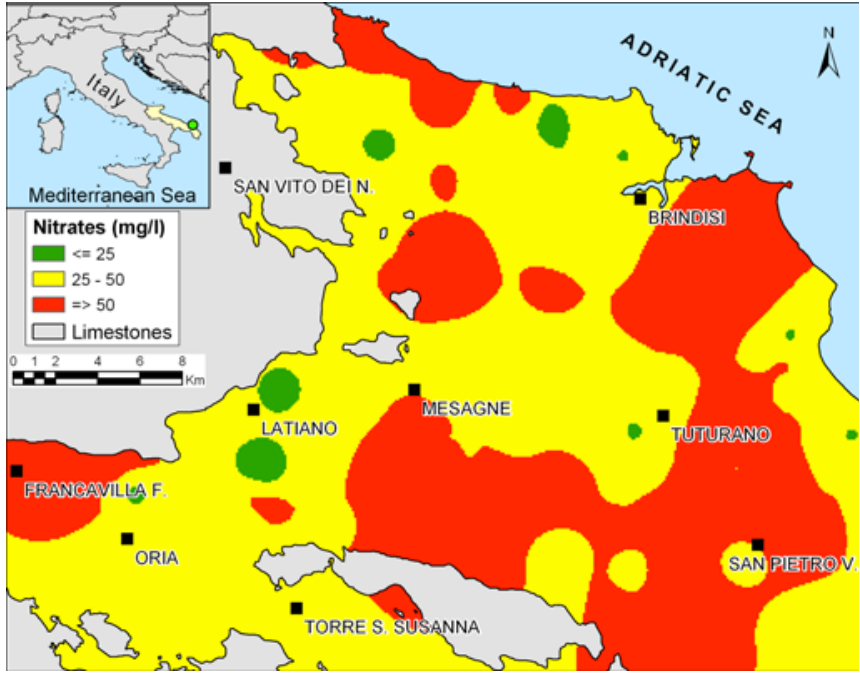

Fig. (9). Estimation map of nitrates concentration in the shallow aquifer.

The map shows how the most contaminated water from the "shallow" groundwater is that S and SE of Brindisi, in the northern coastal section and south of the MesagneTuturano alignment. In these areas, over $40 \%$ of the "dug wells" sampled have water with a concentration of nitrates exceeding 4 times the M.A.C. with maximum values of 1300 $\mathrm{mg} / \mathrm{l}$ in the area of Francavilla Fontana.

A similar quality control was performed on the waters of the "deep groundwater" and from the map reported in Fig. (10) it can be asserted that the water body has not yet been heavily affected by pollution: the waters with concentrations of nitrates higher than $50 \mathrm{mg} / \mathrm{l}$ are isolated to the south of Mesagne. In this area the nitrate concentrations in the deep groundwater varied from $70 \mathrm{mg} / \mathrm{l}$ to over $170 \mathrm{mg} / \mathrm{l}$. Repeated in various periods of the year, we ascertained that they depended on the concentrations recorded in the waters of the "shallow groundwater" which vary from $88 \mathrm{mg} / \mathrm{l}$ to over 260 $\mathrm{mg} / \mathrm{l}$ in the area (Fig. 11).

From the observations made, on the two water bodies and on the thematic maps that the field surveys allowed us to

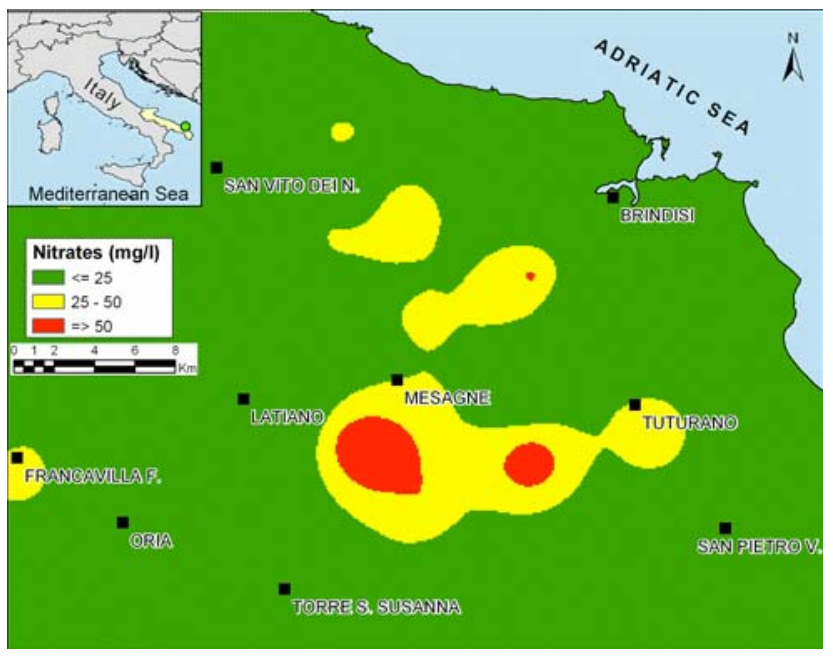

Fig. (10). Nitrate concentration map for the deep aquifer. 
draw up, suitable indications were drawn to discriminate the hydrogeological situations of each individual S.F.E. with the "weight strings". The "weight strings" formulated are those reported in the already mentioned Table $\mathbf{3}$.

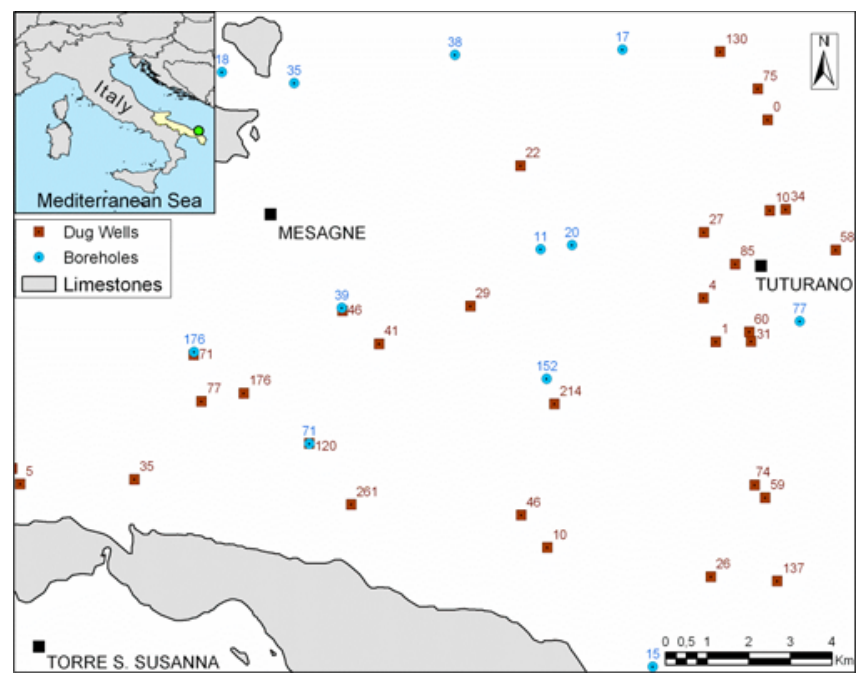

Fig. (11). Nitrate concentration around Mesagne: comparison between deep groundwater and shallow groundwater.

\section{DISCUSSION OF THE RESULTS}

The vulnerability map drawn with the "SINTACS" parameter method integrated with data characterising the quality of the water resources and the presence of potential danger centres, may be considered a possible technical-scientific expression for evaluating the potential risk of pollution of the underground waters.

The study, performed in a large coastal area of Puglia, showed that the groundwater circulating in the "deep" carbonate aquifer, although underlying a densely populated territory, is protected by a thick layer of clay at the base of the "shallow" aquifer.

From analysis of the maps regarding the intrinsic vulnerability of the two aquifers, it can, indeed, be seen that: the "deep" hydrogeological environment has a contained intrinsic vulnerability in terms of variability and of a "medium""high" degree (Fig. 12); moreover, in some limited zones in proximity to the coastal area, it is affected by the action of the intruding seawater.

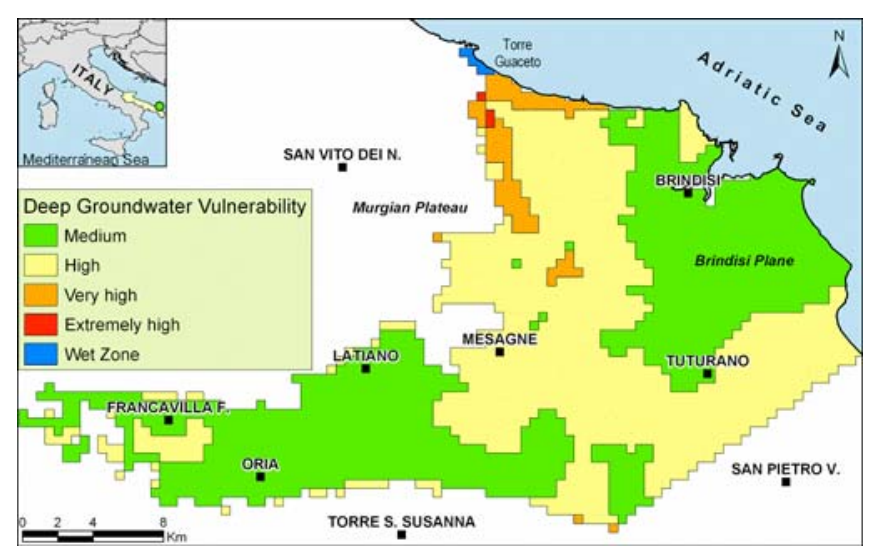

Fig. (12). Vulnerability map of deep aquifer in the North Salento.
The "shallow" aquifer, consisting of Quaternary calcarenite-sandy deposits, has an extremely variable degree of vulnerability ranging from: "High" over "Very high" to "Extremely high" over $70 \%$ of the investigated territory (Fig. 13). This high degree of vulnerability can be put down to a low depth to groundwater which makes both the travel time of the hydrovectored contaminant and the duration of the unsaturated zone attenuation actions minimum. These particular conditions also affect the quality of the groundwater which is significantly influenced by the products used in agriculture.

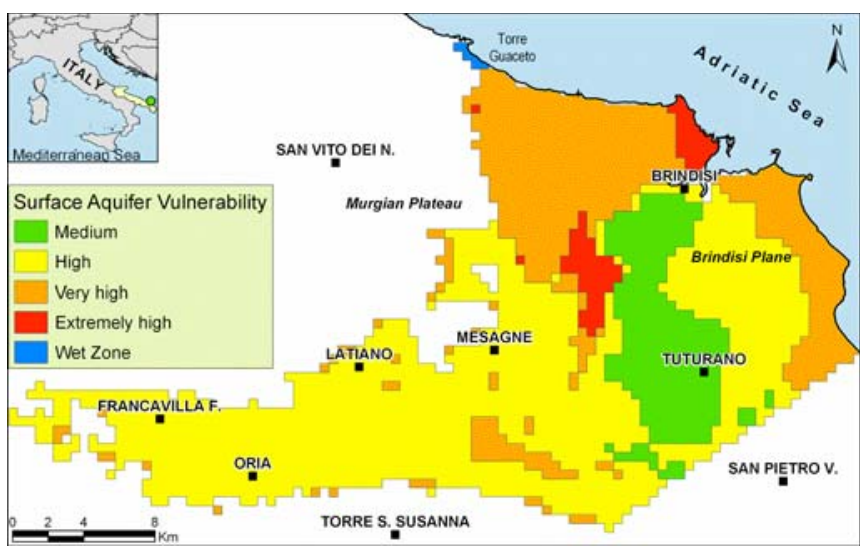

Fig. (13). Vulnerability map of shallow aquifer in the North Salento.

Moreover, by comparing the vulnerability maps (Figs. $12,13)$ with that of the concentration of nitrates in the deep groundwater (Fig. 10) it can be seen that in some zones of the carbonate aquifer, characterized by "low" vulnerability, the concentration of nitrates in the water is quite high.

As already described accurately above, this localized presence of nitrous substances in the "deep" groundwater, is due to the infiltration of irrigation water. As a result of the described geological-structural articulation, these forms of pollution limited to some water pumping wells are probably caused by the poor drawing system employed. Indeed the borehole made to create the "deep" wells, when crossing the clayey level which separates the two aquifers, put the "shallow" aquifer in contact with the "deep" one. Considering such conditions, the possible solutions are the draining of polluted water and the achievement of impervious barriers finalized to separate two aquifers where are in contact: in this last case, the practical solution consists in closing the existing wells near the polluted areas.

In these hydrogeological situations, isolating the section which crosses the first aquifer is advisable when creating water pumping wells, to prevent the "shallow" waters from percolating into the "deep" environment.

\section{ACKNOWLEDGEMENTS}

The authors acknowledge the financial contributions of Project 10 - Cluster 11/b "Earth's Environment", funded by Italian Ministry of University and Scientific and Technological Research (MURST).

Also, the authors would like to thank M. Clark for his help in drawing up the English version of this paper. 


\section{LIST OF ABBREVIATIONS AND ACRONYMS}

DEM = Digital Elevation Model, digital representation of ground surface topography or terrain. Its elaborations and derivates permit to extract various terrain parameters as slope, aspect, etc.

DRASTIC $=$ Depth to water, net Recharge, Aquifer media, Soil media, Topography, Impact of vadose zone, hydraulic Conductivity of the aquifer, a PCSM (see) for assessment of aquifer intrinsic vulnerability to pollution.

GIS $=$ Geographic Information System, an advanced computing systems for management and analysis of vector and raster geographic data.

M.A.C. $=$ Maximum Admitted Concentration, according to Italian law (Decree Law 152/06)

PCSM = Point Count System Model, a parametric system adopting rating and weight to assess the aquifer vulnerability to pollution

SFE $=$ Square Finite Elements, each of the grid cells that subdivide the territory subjected to analysis by a parametric model

SINTACS $=$ Soggiacenza (depth to groundwater), Infiltrazione efficace (effective infiltration), azione del Non saturo (unsaturated zone attenuation capacity), Tipologia della copertura (Soil/overburden attenuation capacity), caratteri Idrogeologici dell' acquifero (aquifer hydrogeologic features), Conducibilità idraulica (hydraulic conductivity), acclività della Superficie topografica (topographic surface average slope).

\section{REFERENCES}

[1] F. Zezza, "Lithological properties and geological conditions of carbonatic platform deposits related to karstic groundwater circulation in Southern Italy", Geolologia Applicata ed Idrogeolologia, vol.13, pp. 393-416, 1978.

[2] D. Grassi, T. Tadolini, "Hydrogeology of the mesozoic carbonate platform of Apulia (South Italy) and the reasons for its different aspects", International Symposium on karst water resources, Ankara, Turkey, pp. 293-306, 1985

[3] D. Sciannamblo, M. Spizzico, T. Tadolini, R. Tinelli, "Lineamenti idrogeologici della zona umida di Torre Guaceto (Br)", Geologica Romana, vol. 30, pp. 754-760, 1992.

[4] M. Spizzico, "Radium and Radon Content in the Carbonate Aquifer of the Southern Italian Region of Apulia". Hydrogeology Journal, vol. 4, pp. 450-454, 2005.

[5] M. Civita, "Groundwater vulnerability maps: a review", In Proceedings of the IX symposium on pesticide chemistry "mobility and degradation of xenobiotics", Piacenza, pp. 587-631, 1993.
[6] M. Civita, "Le Carte della vulnerabilita' degli acquiferi all'inquinamento. Teoria e Pratica", Bologna: Pitagora Editrice, p. 325, 1994.

[7] L Aller, T. Bennett, J.H. Lehr, R.H. Petty, G. Hackett, "DRASTIC: A standardised system for evaluating groundwater pollution potential using hydrogeologic settings", US EPA Report 600/2-87/035, Robert S. Kerr Environmental Research Laboratory, Ada, Oklahoma, pp. 622, 1987

[8] M. Civita, M. De Maio, "Mapping groundwater vulnerability in areas impacted by flash food disasters", 13th ESRI European User Conference, Firenze (ITALY), 7-9 October 1997 [Online]. Available: http://gis.esri.com/library/userconf/europroc98/proc/idp51.html [Accessed 1998].

[9] A. Marsico, G. Giuliano, L. Pennetta, M. Vurro "Intrinsic vulnerability assessment of the south-eastern Murge (Apulia, southern Italy)", Natural Hazards and Earth System Sciences, European Geosciences Union Ed., vol. 4, pp. 769-774, 2004.

[10] M. Al Kuisi, A. El-Naqa N. Hammouri, "Vulnerability mapping of shallow groundwater aquifer using SINTACS model in the Jordan Valley area, Jordan", Environmental Geology, vol. 50, pp. 651667, 2006.

[11] M. Draoui, J. Vias, B. Andreo, K Targuisti., J. Stitou El Messari, "A comparative study of four vulnerability mapping methods in a detritic aquifer under mediterranean climatic conditions", Environmental Geology, vol. 54, pp. 455-463, 2008.

[12] N. Ciaranfi, P. Pieri, G. Ricchetti, "Note alla carta geologica delle Murge e del Salento (Puglia centromeridionale)", Memorie Societa Geologica Italiana, vol. 41, pp. 449-460, 1992.

[13] N. Lopez, D. Sciannamblo, V. Spizzico, "Intrinsic vulnerability assessment for apulian coastal aquifer using the SINTACS model", Giornale di Geologia Applicata, vol. 2, pp. 158-166, 2005a.

[14] N. Lopez, D. Sciannamblo, M. Spizzico, R. Tinelli, "Characterizing the post-cretaceous aquifer in the Brindisi plain (south Italy) in order to recover and protect underground bodies of recover and protect underground bodies of water", Book of proceedings of 3rd symposium "Quality and Management of water resources", Saint Petersburg, RUSSIA, pp.341-351, 2005 b.

[15] M. Civita, M. De Maio,"SINTACS R5 - A new parametric system for the assessment and automatic mapping of ground water vulnerability to contamination”, Bologna: Pitagora Editrice, p. 226, 2000.

[16] M. Spizzico, N. Lopez, D. Sciannamblo, "Applicazione del modello parametrico SINTACS all'acquifero costiero pugliese", Atti XXIX Convegno di Idraulica e Costruzioni Idrauliche, vol. 2, pp. 641-649, 2004

[17] Regione Puglia, "Pedological Informative System of Apulian Region: Pedological Map". ACLA I, ACLA II and INTERREG II Italy-Albania Projects. [Online]. Available: http://www. cartografico.puglia.it/cartomdb/ [Accessed 2001].

[18] D. Dent, A. Young, Soil Survey and Land Evaluation. London: Allene Unwin, 1981

[19] J.R. Landon, Booker Tropical Soil Manual New York: Booker Agriculture International Limited, Longman, pp. 450, 1984

[20] M. Spizzico, N. Lopez, D. Sciannamblo, R. Tinelli, "The Plane of Brindisi: interaction phenomena between groundwaters present in the area", Giornale di Geologia Applicata, vol. 3, pp. 17-24, 2006.

[21] A. Castrignanò, N. Lopez, M. Spizzico, D. Sciannamblo, "Characterization of the quality of Brindisi Plane's surface groundwater using geostatistical methods", Giornale di Geologia Applicata, vol. 3 , pp. 7-16, 2006.

[22] P. Goovaerts, Geostatistics for Natural Resources Evaluation. New York: Oxford Univ. Press, 1997.

[23] R. Webster, M.A. Oliver, Statistical methods in Soil and Land Resources Survey. Oxford University Press, 2000.

(C) Lopez et al.; Licensee Bentham Open.

This is an open access article licensed under the terms of the Creative Commons Attribution Non-Commercial License (http://creativecommons.org/licenses/by-nc/3.0/) which permits unrestricted, non-commercial use, distribution and reproduction in any medium, provided the work is properly cited. 